\title{
Pembuatan Silase Rumput Gajah Odot (Pennisetum purpureum cv. Mott) dengan Penambahan Berbagai Dosis Molasses
}

\section{Making Silage of Odot Elephant Grass (Pennisetum purpureum cv. Mott) with Preservative Molasses}

\author{
M. Landupari*, A. H. B. Foekh, dan K. B. Utami \\ Program Studi Penyuluhan Peternakan dan Kesejahteraan Hewan, Politeknik Pembangunan Pertanian, \\ Malang - Indonesia \\ *Corresponding E-mail: martialandupari.stppmalang@gmail.com \\ (Diterima: 14 Januari 2020; Disetujui: 30 Mei 2020)
}

\begin{abstract}
ABSTRAK
Penelitian ini bertujuan untuk mengevaluasi pengaruh penambahan level molasses terhadap kualitas fisik (warna, aroma, tekstur dan keberadaan jamur) silase rumput gajah odot. Penelitian dilakukan di Laboratorium Pakan dan Nutrisi Ternak Polbangtan Malang. Bahan yang digunakan yaitu rumput odot, dan molasses. Rancangan penelitian menggunakan Rancangan Acak Lengkap (RAL) dengan 3 perlakuan dan 6 ulangan. Perlakuan adalah level penambahan molasses terdiri dari $\mathrm{P}_{0}=$ rumput odot $+0 \%$ molasses, $\mathrm{P}_{1}=$ rumput odot $+3 \%$ molasses, dan $\mathrm{P}_{2}=$ rumput odot $+6 \%$ molasses. Waktu penyimpanan selama 21 hari. Pengamatan dilakukan pada hari ke 21. Variabel yang diukur adalah kualitas fisik silase rumput gajah odot meliputi: warna, aroma, tekstur, dan keberadaan jamur. Hasil penelitian menunjukan bahwa level penambahan molasses tidak berpengaruh nyata $(\mathrm{P}>0,05)$ terhadap warna, tekstur dan keberadaan jamur pada silase tetapi berpengaruh nyata $(\mathrm{P}<0,05)$ terhadap aroma dimana semakin banyak diberi molasses maka silase beraroma semakin asam. Kesimpulan dalam penelitian ini adalah penggunaan molasses yang berbeda dosis tidak berpengaruh nyata terhadap warna, tekstur, dan keberadaan jamur, tetapi berpengaruh nyata terhadap aroma silase. Pemberian molasses $6 \%$ memberikan hasil kualitas aroma silase yang baik.
\end{abstract}

Kata kunci: molasses, pakan, rumput gajah odot, silase

\section{ABSTRACT}

The purpose of the study was to evaluate the effect of molasses level on the physical quality of odot grass silage (Color, aroma, texture, and presence of fungi in the silage). This research was done in the Animal Feed and Nutrition Laboratory of Polbangtan Malang. The materials used were odot grass and molasses. The research design was a completely randomized design (CRD) with three treatments and six replications. The treatment were the level of molasses used in the silage consisted of $P 0=$ odot grass + $0 \%$ molasses, $P 1=$ odot grass $+3 \%$ molasses and $P 2=$ odot grass $+6 \%$ molasses with a storage time of 21 days. The variables measured on the 21st day. They were the physical quality of the elephant odot grass silage consisted of: color, aroma, texture, and presence of fungi. The results showed that there was no significant effect $(P>0.05)$ on the color, texture, and presence of fungi on silage. Still, they had a significant effect $(P<0.05)$ on the aroma, where more molasses were more scented silage. The conclusions in this study were: the level of molasses had no significant effect on the color, texture, and presence of fungi but had a significant effect on the aroma of silage. The administration of $6 \%$ molasses gave a good quality of silage aroma.

Keywords: dosis, molasses, grass elephant odot, silage 


\section{PENDAHULUAN}

Pakan adalah salah satu kebutuhan yang paling penting dalam usaha peternakan ruminansia. Pakan inilah yang memenuhi kebutuhan hidup akan ternak itu sendiri. Sehingga keterseddiaan pakan harus selalu terjaga. Pakan yang umum diberikan pada ternak kambing adalah rerumputan, atau hijauan, dedak, konsentrat dan vitamin atau suplemen tambahan (Muttaqin et al., 2011). Menurut Harahap (2017) masalah kelangkaan pakan dapat menurunkan produktivitas ternak. Penyediaan pakan berkualitas dapat dilakukan dengan pemberian rumput lapang, dan dapat juga dengan memanfaatkan berbagai limbah pertanian.

Agar pakan selalu tersedia maka peternak harus memperhatikan ketersediaan pakan hijauan untuk ternak. untuk menjaga ketersediaan tersebut maka memerlukan usaha untuk mengatasi masalah kekurangan pakan bagi peternak yakni dengan melakukan inovasi penyimpanan pakan segar dalam jangka waktu tertentu. Inovasi tersebut adalah dengan mengawetkan bahan hijauan segar dalam hal ini membuat silase. Sehingga ketika kesulitan dalam mencari pakan pada musim kemarau bisa diatasi dengan membuat silase. Silase merupakan pakan ternak ruminansia yang dapat dibuat dari berbagai macam jenis hijauan pakan dan juga limbah pertanian. Salah satu usaha dalam mengatasi kekurangan pakan hijauan pada musim kemarau adalah dengan melakukan pengawetan bahan pakan hijauan dalam bentuk silase (Rukmana, 2001). Rumput Pennisetum purpureum cv. mott dikenal dengan nama lokal gajah mini atau rumput odot ditemukan pertama kali dan dikembangkan di Tulung Agung Jawa Timur oleh seorang peternak kambing PE bernama Bapak Odot (Sirait, 2017). Penggunaan bahan pengawet merupakan salah satu cara agar meningkatkan kualitas silase yang baik sehingga dalam pembuatan silase perlu adanya bahan pengawet yang bisa meningkatkan kualitas silase. Menurut Yunus (2009) salah satu bahan yang sering digunakan dalam pembuatan silase adalah molasses yang merupakan hasil sampingan dari pembuatan gula pasir dari tebu yang mempunyai sifat menyedapkan bahan makanan ternak. Molasses sering disebut Tetes tebu. Tetes tebu rendah protein dan dalam proses silase protein sangat diperlukan untuk dirombak menjadi amoniak, asam amino, asam asetat. Pada prinsipnya pembuatan silase adalah mempertahankan kondisi kedap udara dalam silo semaksimal mungkin (Hidayat, 2014).

\section{METODE}

Kajian Teknis dilakukan di Laboratorium Pakan dan Nutrisi Ternak Polbangtan Malang dan penyuluhan dilakukan di Desa Beji Kecamatan Junrejo Kota Batu. Desain penelitian menggunakan rancangan acak lengkap (RAL) dengan 3 perlakuan dan 6 kali ulangan. Perlakuannya adalah dosis penggunaan molasses dalam pembuatan silase rumput gajah odot sebagai berikut : P0 $=$ rumput gajah odot $+0 \%$ molasses, $\mathrm{P} 1=$ rumput gajah odot $+3 \%$ molasses dan $\mathrm{P} 2=$ rumput gajah odot $+6 \%$ molasses.

Pelaksanaan penelitian. Hijauan rumput gajah odot dicacah kurang lebih $3-5 \mathrm{~cm}$ bisa dengan mencacah manual atau bisa juga dengan mengunakan alat chopper. Kapasitas silo yang digunakan adalah kapasitas $3 \mathrm{~kg}$ tetapi ketika dipadatkan semakin banyak sehingga dalam satu silo masing-masing kurang lebih membutuhkan $6 \mathrm{~kg}$ hijauan. Bahan untuk membuat silase dicampur merata kemudian mengisi silo sampai penuh sambil ditekan agar rapat setelah itu silo ditutup rapat dan disimpan selama 21 hari. Pengambilan sampel untuk dianalisa adalah setelah 21 hari penyimpanan. Variabel yang diamati adalah kualitas fisik yaitu warna, aroma, tekstur dan keberadaan jamur.

\section{HASIL DAN PEMBAHASAN}

Hasil penilaian secara fisik yang mencakup warna, aroma, tekstur dan 
Tabel 1. Rataan karakteristik fisik silase rumput gajah odot dengan level penggunaan molasses

\begin{tabular}{lcccc}
\hline \multirow{2}{*}{ Komposisi Perlakuan } & \multicolumn{4}{c}{ Parameter } \\
\cline { 2 - 5 } & Warna & Aroma & Tekstur & Keberadaan Jamur \\
\hline $\mathrm{P}_{0}$ (Rumput Odot $+0 \%$ & $2,3^{\mathrm{a}} \pm 0,516$ & $2,0^{\mathrm{a}} \pm 0,000$ & $1,6^{\mathrm{a}} \pm 0,516$ & $3,0^{\mathrm{a}} \pm 0,000$ \\
Molasses) & & & \\
$\mathrm{P}_{1}$ (Rumput Odot $+3 \%$ & $2,5^{\mathrm{a}} \pm 0,547$ & $2,0^{\mathrm{a}} \pm 0,632$ & $1,8^{\mathrm{a}} \pm 0,752$ & $2,8^{\mathrm{a}} \pm 0,408$ \\
$\begin{array}{l}\text { Molasses) } \\
\mathrm{P}_{2} \text { (Rumput Odot }+6 \%\end{array}$ & $2,0^{\mathrm{a}} \pm 0,000$ & $3,0^{\mathrm{b}} \pm 0,000$ & $2,1^{\mathrm{a}} \pm 0,408$ & $2,8^{\mathrm{a}} \pm 0,408$ \\
Molasses)
\end{tabular}

Keterangan: Superskrip yang berbeda pada kolom yang sama menunjukkan perbedaan yang nyata $(p<0,05)$

keberadaan jamur. Pengaruh penambahan molasses dengan dosis yang berbeda terhadap kualitas fisik silase rumput gajah odot disajikan pada Tabel 1.

Tabel 1 menunjukan perlakuan memberikan pengaruh yang tidak nyata terhadap warna, tekstur dan keberadaan jamur untuk semua perlakuan, tetapi berpengaruh nyata terhadap aroma silase. Hasil uji lanjut didapatkan bahwa $\mathrm{P}_{2}$ dengan dosis molasses $6 \%$ yaitu beraroma asam. Sedangkan warna silase yaitu kuning kecoklatan, tekstur agak lembek serta tidak berjamur. Hal ini menunjukkan bahwa penambahan molasses dengan dosis yang berbeda tidak memberikan pengaruh negatif terhadap proses fermentasi.

\section{Warna}

Warna silase merupakan salah satu penilaian dari kualitas fisik silase. Hasil penelitian didapatkan perlakuan memberikan pengaruh yang tidak nyata $(\mathrm{P}>0,05)$ terhadap warna silase. Dimana semua perlakuan menghasilkan warna hijau gelap/kuning kecoklatan karena selama proses penyimpanan silase berlangsung dengan baik dan tidak adanya proses respirasi yang panjang yang mengakibatkan silase berwarna kehitaman. Warna coklat pada silase disebabkan karena adanya pigmen phatophitin suatu derivate chlorophil yang tak ada magnesiumnya (Hidayat, 2014). Silase yang sudah dibuat disimpan pada ruangan yang teduh tanpa sinar matahari sehingga suhu ruangan normal yakni $20-25^{\circ} \mathrm{C}$ dimana hal tersebut tidak berpengaruh negatif pada silase yang dibuat.
Menurut Kojo et al. (2015) temperatur yang tidak dapat dikendalikan yakni pada $55^{\circ} \mathrm{C}$ dapat menyebabkan silase berwarna coklat tua sampai hitam dan ini mengakibatkan turunnya nilai kandungan nutrisi pakan karena karbohidrat banyak yang hilang. Wati et al. (2018) menyatakan bahwa warna silase yang hijau cerah atau hijau kecoklatan merupakan warna normal untuk silase rerumputan sedangkan kuning kecoklatan merupakan warna silase rumput yang dilayukan.

\section{Aroma}

Salah satu indikator untuk menilai kualitas fisik dari silase adalah dari aroma silase. Aroma secara umum untuk hasil silase yang baik adalah aroma asam karena pada proses ensilase terjadi proses fermentasi. Hasil analisisi statistik menunjukkan bahwa level molasses pada pembuatan silase rumput gajah odot memiliki pengaruh yang nyata terhadap aroma silase $(\mathrm{P}>0,05)$. Scor aroma untuk $\mathrm{P}_{0}(0 \%$ molasses $)$ dan $\mathrm{P}_{1}(3 \%$ molasses) nyata lebih rendah dibandingkan dengan aroma silase pada $\mathrm{P}_{2}(6 \%$ molasses $)$. Hal ini menunjukan bahwa semakin banyak dosis molasses yang diberikan mengakibatkan silase beraroma semakin asam karena adanya pertumbuhan bakteri asam laktat selama proses fermentasi. Kurnianingtyas et al. (2012) melaporkan bahwa pemberian molasses menghasilkan kualitas fisik yang baik yaitu bau asam atau wangi fermentasi dan tidak terdapat aroma busuk. Pendapat Kurniawan et al. (2015) Pertumbuhan bakteri asam laktat mengakibatkan produksi asam 
laktat meningkat disitu terjadi kondisi asam. Larangahen et al. (2017) menyatakan bahwa semakin banyak diberikan molasses dan disimpan dalam waktu yang lama maka baunya akan berubah sedikit asam karena molasses tersebut adalah sumber energi (glukosa) yang menyebabkan adanya perubahan bau silase. Bau asam yang dihasikan oleh silase itu terjadi karena proses ensilase bakteri anaerob aktif bekerja menghasilkan asam organik (Syafi'i dan Rizqina, 2017).

\section{Tekstur}

Hasil pengamatan fisik silase rumput gajah odot menunjukkan bahwa penggunaan molasses dengan level yang berbeda tidak berpengaruh nyata pada tekstur silase rumput gajah odot. Silase rumput gajah odot dengan pemberian molasses yang berbeda menghasilkan rataan skor penilaian berada pada kisaran 1,6 - 2,1. Hal ini menunjukkan bahwa silase yang dibuat tanpa pemberian molasses menghasikan kualitas tekstur agak lembek, begitupun pada silase dengan penambahan molasses 3\% dan $6 \%$ memiliki kualitas tekstur agak lembek. Tekstur silase dipengaruhi oleh kadar air pada hijauan dan kadar molasses. Sehingga dalam kajian yang dilakukan ini diduga kadar air silase terlalu tinggi sehingga tekstur silase agak lembek. Hidayat et al. (2012) menyatakan bahwa silase dikatakan berhasil jika proses ensilase menghasilkan tekstur silase yang remah. Kurniawan et al. (2015) menyatakan bahwa selama prosess ensilase berlangsung maka terjadi penurunan bahan kering dan peningkatan kadar air yang disebabkan oleh tahap ensilase pertama dimana respirasi masih terus berlangsung glukosa diubah menjadi $\mathrm{CO}_{2}, \mathrm{H}_{2} \mathrm{O}$, dan panas. Kadar air yang tinggi pada hijauan menyebabkan air tirisan banyak sehingga oksigen dalam silo juga meningkat (Chalisty et al., 2017).

\section{Keberadaan Jamur}

Data hasil statistik menunjukkan bahwa silase dengan penambahan molasses dengan dosis yang berbeda tidak berpengaruh nyata terhadap keberadaan jamur dalam silase rumput gajah odot. Hal ini disebabkan bahwa proses ensilase terdapat bakteri asam laktat yang berkembang dengan baik sehingga tidak terdapat jamur pada silase yang dibuat. Santi et al. (2012) akselerator mempercepat fase anaerobik karena bakteri penghasil asam laktat (Lactobacillus) memanfaatkan akselerator yang ditambahkan untuk menurunkan $\mathrm{pH}$ dan jamur atau bakteri pembusuk tidak berkembang. Herlinae et al. (2015) menyatakan bahwa dalam proses ensilase apabila oksigen telah habis terpakai pernapasan akan berhenti dan suasan menjadi anerob. Dalam keadan demikian jamur tidak dapat tumbuh dan hanya bakteri yang masih aktif terutama bakteri pembentuk asam. Chalisty et al. (2017) keberadaan jamur keseluruhan atau sebagian disebabkan karena bagian permukaan tempat pengikatan silo masih terdapat kemungkinan proses ensilase yang tidak sepenuhnya anaerob, kondisi inilah yang mengakibatkan oksigen masuk dan menimbulkan jamur tumbuh.

\section{KESIMPULAN}

Simpulan penelitian ini adalah level penambahan molasses berpengaruh tidak nayata pada warna, tekstur dan keberadaan jamur tetapi pemberian molasses $6 \%$ berpengaruh nyata terhadap aroma silase. Semakin banyak diberikan molasses maka kualitas silase semakin baik aroma silase.

\section{DAFTAR PUSTAKA}

Chalisty, V. D., Utomo, R. dan Bachruddin, Z. 2017. Pengaruh Penambahan Molasses, Lactobacillus plantarum, Tricoderma Viride dan Campurannya Terhadap Kualitas Silase Total Campuran Hijauan. Buletin Peternakan. 41(4): $431-438$.

Harahap, A. E. 2017. Kualitas Bakteri Asam Laktat Isolasi Jerami Padi dengan Penambahan Berbagai Level Molasses. Jurnal Peternakan. 14(1): 25 - 30. 
Herlinae., Yemima, dan Rumiasih. 2015. Pengaruh Aditif EM4 dan Gula Merah Terhadap Karakteristik Silase Rumput Gajah (Pennisetum purpureum). Jurnal Ilmu Hewani Tropika. 4(1).

Hidayat, N. 2014. Karakteristik dan Kualitas Silase Rumput Raja Menggunakan Berbagai Sumber dan Tingkat Penambahan Karbohidrat Fermentable. Jurnal Ilmiah Fakultas Peternakan Universitas Jenderal Soedirman, Purwokerto. Agripet . 14(1): 42 - 49.

Hidayat, N., Widiyastuti, T. and Suwarno. 2012. The Usage of Fermentable Carbohydrates and Level of Lactic Acid Bacteria on Physical and Chemical Characteristicts of Silage. Prosiding Seminar Nasional "Pengembangan Sumber Daya Pedesaan dan Kearifan Lokal Berkelanjutan II" Purwokerto, $27-28149$.

Kojo, R. M., Rustandi., Tulung, Y. R. L. dan Malalantang. 2015. Pengaruh Penambahan Dedak Padi pada Tepung Jagung Terhadap Kualitas Silase Rumput Gajah. Jurnal Zootek. 35(1): $21-29$.

Kurnianingtyas, I. B., Pandansari, P. R., Astuti, I., Widyawati, S. D. dan Suprayogi, W.P.S. 2012. Pengaruh Macam Akselerator terhadap Kualitas Fisik, Kimiawi, dan Biologis Silase Rumput Kolonjono. Tropical Animal Husbandry. 1(1): 7 - 14.

Kurniawan, D., Erwanto, dan Fathul, F. 2015. Pengaruh Penambahan Berbagai Starter pada Pembuatan Silase terhadap Kualitas Fisik dan pH Silase Ransum Berbasis Limbah Pertanian. Jurnal Ilmiah Peternakan Terpadu. 3(4): 191 $-195$.
Larangahen, A., Bagau, B., Imbar, M. R. dan Liwe, H. 2017. Pengaruh Penambahan Molases terhadap Kualitas Fisik dan Kimia Silase Kulit Pisang Sepatu (Mussa paradisiaca formatypica). Jurnal Zootek (“Zootek" Journal). 37(1): $156-166$.

Muttaqin, M. I. H. dan Novia, A. 2011. Beternak Sapi Kambing, dan Domba Potong. Cahaya Atma, Yogyakarta.

Rukmana, H. R. 2001. Silase dan Permen Ternak Ruminansia. Teknologi Tepat Guna. Kanisius, Yogyakarta.

Santi, R. K., Fatmasari, D., Widyawati, S. D. dan Suprayogi, W. P. S. 2012. Kualitas dan Nilai Kecernaan In Vitro Silase Batang Pisang (Musa paradisiaca) dengan Penambahan Beberapa Akselerator. Tropical Animal Husbandry. 1(1): 15 - 23.

Sirait, J. 2017. Rumput Gajah Mini (Pennisetum purpureum cv. Mott) sebagai Hijauan Pakan untuk Ruminansia. WARTAZOA. 4(27): 167 -176 .

Syafi'i dan Riszqina. 2017. Kualitas Silase Rumput Gajah Dengan Bahan Pengawet Dedak Padi Dan Tepung Gaplek. MADURANCH. 2(2).

Wati, S. W. Mashudi. Irsyammawati, A. 2018. Kualitas Silase Rumput Odot (Pennisetum Purpureum cv. mott) Dengan Penambahan Lactobacillus Plantarum dan Molasses pada Waktu Inkubasi yang Berbeda. Jurnal Nutrisi Ternak Tropis. 1(1): 45 - 53.

Yunus, M. 2009. Pengaruh Pemberian Daun Lamtoro (Leucaena leocephala) terhadap Kualitas Silase Rumput Gajah (Pannisetum purpereum) yang Diberi Molasses. Agripet. 9(1). 